\title{
KEMAMPUAN GURU MATEMATIKA MEMPERTAHANKAN SUBSTANSI MATERI MELALUI PROSES PEMBELAJARAN ONLINE
}

\author{
Febri Giantara ${ }^{1}$ Astuti $^{2}$ \\ ${ }^{1}$ STAI Diniyah Pekanbaru, Jl. Kuau No.01, Kp. Melayu, Kec. Sukajadi, Pekanbaru, Riau \\ ${ }^{2}$ Universitas Pahlawan Tuanku Tambusai, Jl. Tuanku Tambusai No 23 Bangkinang, Riau \\ Febri@diniyah.ac.id
}

\begin{abstract}
The online learning process is carried out by all subject teachers in the Regency and City of Riau Province, including mathematics teachers. Learning mathematics is not learning that as a whole is abstract, but there are materials that require the teacher to relate it to the real life of students. Departing from this, this study wants to see the ability of mathematics teachers to maintain material through the online learning process. This research method is descriptive quantitative research. Analysis of descriptive quantitative research data is frequency: count the number of occurrences of a category, size of concentration, and size of distribution. The results obtained are that the mathematics teacher is very concerned about providing motivation, feedback, and achieving online learning goals. For future improvements, it is expected that mathematics teachers pay attention to the quality of the content presented and pay attention to the inclusion of IPR elements in the creation of learning content.
\end{abstract}

Keywords: Teacher Ability, Mathematics, On line

\begin{abstract}
Abstrak
Proses pembelajaran online dilaksanakan oleh semua guru mata pelajaran yang ada di Kabupaten dan Kota di Provinsi Riau, tidak terkecuali guru matematika. Pembelajaran matematika bukanlah pembelajaran yang secara keseluruhan bersifat abstrak tetapi terdapat materi-materi yang mengharuskan guru mengaitkannya dengan kehidupan nyata siswa. Berangkat dari hal tersebut penelitian ini ingin melihat kemampuan guru matematika mempertahankan materi melalui proses pembelajaran online. Metode penelitian ini merupakan penelitian kuantitatif deskriptif. Analisis data penelitian kuantitatif deskriptif adalah frekuensi: hitung jumlah kemunculan suatu kategori, ukuran pemusatan, dan ukuran penyebaran. Hasil yang diperoleh adalah guru matematika sangat memperhatikan pemberian motivasi, umpan balik, dan tercapainya tujuan pembelajaran online. Untuk perbaikan kedepannya diharapkan kepada guru matematika agar memperhatikan kualitas konten yang disajikan dan memperhatikan ketermasukan unsur-unsur HKI pada pembuatan konten pembelajaran.
\end{abstract}

Kata kunci: Kemampuan Guru, Matematika, Pembelajaran Online.

\section{PENDAHULUAN}

Kasus pertama virus corona di Indonesia diumumkan oleh Presiden Jokowi pada tanggal 02 Maret 2020 (Ihsanuddin, 2020). Semenjak pengumuman kasus pertama, penyebaran virus corona di Indonesia terus menunjukkan tren naik dari hari kehari. Tren tersebut mengakibatkan pemerintah harus mengambil beberapa langkah. Salah satu langkah yang diambil pemerintah terkait dunia pendidikan adalah menjalankan seluruh proses pendidikan melalui proses online disemua jenjang pendidikan, dimulai dari pendidikan anak usia dini sampai dengan perguruan tinggi. Sebuah keputusan yang sulit harus dijalankan oleh para guru dan siswa dengan segala keterbatasan yang ada, memanfaatkan berbagai macam media online yang tersedia dan proses pembelajaran online tersebut bersifat wajib untuk dilaksanakan.

Proses pembelajaran online bukannya tidak mempunyai kendala. Pada penelitian (Handayani, 2020) disampaikan bahwa kendala pembelajaran online tersebut dimulai dari ketidakstabilan jaringan, suara guru dan bahan ajar tidak serempak, tidak bisanya siswa belajar ketika jaringan internet tidak terhubung dan berkurangnya konsentrasi dalam belajar. Siswa yang dihadapi oleh guru sekarang 
merupakan generasi millenial. Seperti yang diketahui generasi millenial merupakan generasi yang sangat dekat dengan teknologi dan cenderung lebih singkat berkonsentrasi pada proses pembelajaran. Generasi millenial memiliki tingkat konsentrasi rata-rata 12 detik, sehingga menuntut guru untuk mengemas materi yang disampaikan semenarik mungkin (Daud, 2020). Disamping generasi millenial, guru juga diwajibkan memiliki kompetensi guru abad 21. Kompetensi yang harus dimiliki oleh seorang guru pada abad 21 salah satunya mampu memfasilitasi dan menginspirasi belajar dan kreatifitas peserta didik (Giantara, 2019).

Berangkat dari penelitian tersebut, maka peneliti menemukan permasalahan yang lebih spesifik pada guru matematika yaitu kemampuan guru matematika mempertahankan substansi materi melalui proses pembelajaran. Seperti yang diketahui bahwa pembelajaran matematika bukanlah pembelajaran yang secara keseluruhan bersifat abstrak tetapi terdapat materi-materi yang mengharuskan guru mengaitkannya dengan kehidupan nyata siswa. Mengaitkan materi dengan kehidupan nyata melalui proses online dibutuhkan kreatifitas siswa. Kreatifitas adalah kemampuan subjek menghasilkan banyak jawaban (Ruziana \& Prihatnani, 2019).

Supaya siswa memiliki kreativitas dan mampu mengembangkan kretivitasnya maka diperlukan adanya sebuah instrument untuk mengevaluasi kualitas objek pembelajaran. Salah satu instrument untuk mengevaluasi kualitas objek pembelajaran adalah LORI (Learning Object Review Instrument) yang dikembangkan oleh Nesbet, Belfer dan Leacock (2004) di dalam (Wibawanto, 2017). Terdapat sembilan butir-butir instrument yang dikembangkan oleh LORI, yang dapat dilihat pada tabel di bawah ini:

Tabel 1.

Instrument LORI

\begin{tabular}{|c|l|l|}
\hline No & Kategori & \multicolumn{1}{c|}{ Deskripsi } \\
\hline 1 & Kualitas konten & $\begin{array}{l}\text { Kebenaran, akurasi, keberimbangan penyajian ide, dan ketepatan tingkat } \\
\text { kerincian (keluasan dan kedalaman). Dalam evaluasi objek pembelajaran, } \\
\text { aspek kualitas konten merupakan elemen yang paling menonjol dalam } \\
\text { membentuk kepakaran. Objek pembelajaran, meskipun desainnya } \\
\text { menarik, menjadi tak berguna apabila isinya tidak akurat atau bahkan } \\
\text { menyesatkan. }\end{array}$ \\
\hline 2 & $\begin{array}{l}\text { Keselarasan } \\
\text { dengan tujuan } \\
\text { pembelajaran }\end{array}$ & $\begin{array}{l}\text { Objek pembelajaran dikembangkan sebagai pendukung kegiatan } \\
\text { pembelajaran. Oleh karenanya, evaluasi atas objek pembelajaran harus } \\
\text { mencakup juga keselarasannya dengan tujuan pembelajaran, aktivitas } \\
\text { belajar, asesmen, dan karakteristik peserta pembelajaran. Objek } \\
\text { pembelajaran menjadi kurang efektif apabila ternyata tidak selaras } \\
\text { dengan kegiatan belajar dan asesmennya. }\end{array}$ \\
\hline 3 & Umpan balik & $\begin{array}{l}\text { Pemberian umpan balik dan adaptasi objek pembelajaran terhadap } \\
\text { karakteristik peserta pembelajaran merupakan salah satu cara untuk } \\
\text { mengefektifkan pembelajaran. }\end{array}$ \\
\hline 4 & Motivasi & $\begin{array}{l}\text { Kemampuan objek pembelajaran untuk memotovasi dan menarik } \\
\text { perhatian peserta pembelajaran. Kualitas motivasi objek pembelajaran } \\
\text { mempengaruhi besarnya upaya peserta pembelajaran untuk belajar } \\
\text { dengan objek pembelajaran tersebut. }\end{array}$ \\
\hline 5 & Desain presentasi & \begin{tabular}{l} 
Desain informasi visual dan auditif untuk memperkuat pembelajaran dan \\
\hline
\end{tabular} \\
\hline
\end{tabular}




\begin{tabular}{|c|l|l|}
\hline & & $\begin{array}{l}\text { meningkatkan efisiensi pemrosesan informasi. Desain presentasi merujuk } \\
\text { pada kualitas eksposisi sumber belajar digital. }\end{array}$ \\
\hline 6 & $\begin{array}{l}\text { Usabilitas } \\
\text { interaksi }\end{array}$ & $\begin{array}{l}\text { Konsep usabilitas interaksi diadopsi dari fitur kualitas perangkat lunak } \\
\text { Kemudahan navigasi, keintuitifan antarmuka pengguna (predictability of } \\
\text { the user interface), dan kualitas antarmuka untuk pemberian bantuan } \\
\text { merupakan fitur-fitur yang dinilai dari aspek usabilitas interaksi. }\end{array}$ \\
\hline 7 & Aksesabilitas & $\begin{array}{l}\text { Desain kendali dan format presentasi untuk yang mengakomodasi peserta } \\
\text { pembelajaran berkebutuhan khusus dan yang mengakses bahan ajar } \\
\text { melalui gawai bergerak }\end{array}$ \\
\hline 8 & Reusabilitas & $\begin{array}{l}\text { Potensi untuk digunakan dalam berbagai konteks pembelajaran dan } \\
\text { berbagai latar belakang peserta pembelajaran }\end{array}$ \\
\hline 9 & $\begin{array}{l}\text { Kepatuhan } \\
\text { terhadap standar }\end{array}$ & $\begin{array}{l}\text { Kepatuhan terhadap standar internasional dan spesifikasi standar yang } \\
\text { diikuti }\end{array}$ \\
\hline
\end{tabular}

Pada penelitian ini instrument LORI yang digunakan hanya lima instrument yaitu:

1. Kualitas konten

2. Keselarasan dengan tujuan pembelajaran

3. Umpan balik

4. Motivasi

5. Kepatuhan terhadap standar

Pembatasan hanya kepada lima instrumen didasarkan kepada penilaian ekstrinsik pada sebuah proses pembelajaran. Penelitian ini bertujuan untuk melihat bagaimana kemampuan guru matematika mempertahankan substansi materi melalui proses pembelajaran online dan sebagai bahan kajian lebih lanjut untuk proses pembelajaran matematika melalui proses online ke arah yang lebih baik lagi.

\section{METODE}

Jenis penelitian yang digunakan adalah penelitian kuantitatif deskriptif. Penelitian kuantitatif deskriptif adalah suatu metode penelitian yang ditunjukkan untuk menggambarkan fenomenafenomena yang ada, yang berlangsung saat ini atau saat yang lampau (Sukmadinata, 2010). Langkahlangkah pada penelitian kuantitatif deskriptif adalah sebagai berikut (Leavy, 2017):

1. Tentukan masalah atau bidang yang diamati dan rumuskan submasalah secara jelas dan rinci.

2. Rumuskan secara jelas tujuan yang akan dicapai.

3. Lakukan penelahaan kepustakaan yang tepat dan benar.

4. Rumuskan metodologi penelitian, antara lain:
a. Lakukan prosedur pengumpulan data.
b. Pilih/susun alat/instrument yang tepat.
c. Tentukan populasi dan sampel.
d. Pembakuan instrument.
e. Lakukan latihan pengumpulan data.

5. Turun kelapangan dalam rangka pengumpulan data.

6. Analisis data. 
7. Penulisan laporan.

Subjek dalam penelitian ini guru matematika yang peneliti kenal dan tersebar di berbagai Kabupaten dan Kota yang ada di Provinsi Riau. Guru matematika tersebut mengajar pada jenjang Sekolah Dasar sampai dengan jenjang Sekolah Menengah Atas. Instrument pengumpulan data yang digunakan untuk mengumpulkan data berupa kuesioner tertutup. Kuesioner tertutup adalah kuesioner yang alternatif jawabannya telah disediakan (Wirawan, 2012). Sebelum penyebaran kuesioner dilakukan. Peneliti melakukan uji validitas butir-butir pertanyaan pada kuesioner. Validitas merupakan sebuah dukungan bukti terhadap penafsiran tes sesuai dengan tujuan penggunaan tes (Giantara, 2020). Sedangkan analisis data yang digunakan pada penelitian kuantitatif deskriptif menurut (Leavy, 2017) sebagai berikut:

1. Frekuensi: hitung jumlah kemunculan suatu kategori.

2. Ukuran pemusatan (Mean, Median, dan Modus).

3. Ukuran penyebaran (Simpangan baku, Simpangan Rata-Rata, dan Jangkuan)

\section{HASIL}

Penelitian ini dilakukan selama lebih kurang dua bulan dari bulan Juli sampai dengan bulan Agustus tahun 2020. Langkah awal penelitian dengan menemukan masalah penelitian. Dilanjutkan dengan penyusunan instrument penelitian berupa pertanyaan kuesioner tertutup. Pengujian validitas butir-butir pertanyaan pada instrument penelitian melibatkan ahli pada bidang evaluasi pendidikan, yaitu teman sejawat yang merupakan tamatan program studi evaluasi pendidikan. Masukan yang diberikan oleh teman sejawat tersebut menjadikan langkah awal bagi peneliti untuk melakukan perbaikan.

Pada penelitian ini menggunakan lima indikator yang akan diuraikan sebagai berikut:

1. Indikator Kualitas Konten

Media pembelajaran online yang digunakan
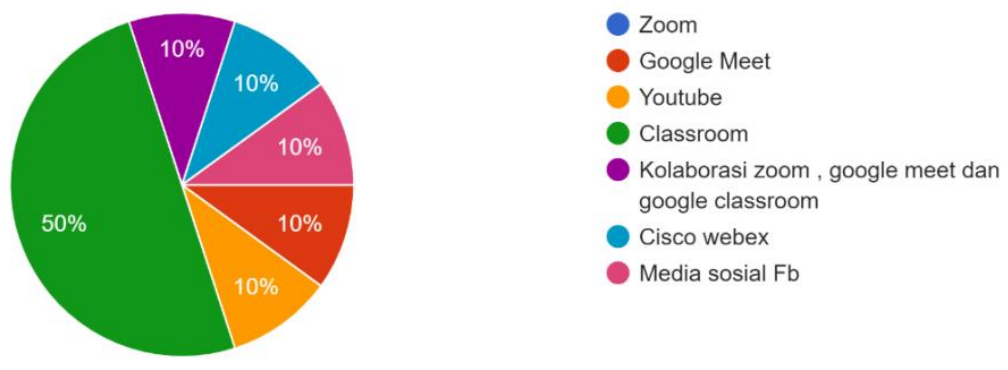

Gambar 1. Indikator Kualitas Konten

Media pembelajaran yang digunakan oleh guru matematika pada proses pembelajaran online 
Kemampuan Guru Matematika Mempertahankan Substansi Materi Melalui Proses Pembelajaran Online, Febri Giantara, Astuti

berdasarkan jawaban yang disampaikan melalui google form terlihat sangat beragam, yaitu Zoom, Google Meet, Youtube, Classroom, Kolobarasi Zoom-Google Meet-Google Classroom, Cisco Webex, dan Facebook.

Melibatkan teman sejawat untuk memvalidasi isi konten pembelajaran online sebelum digunakan
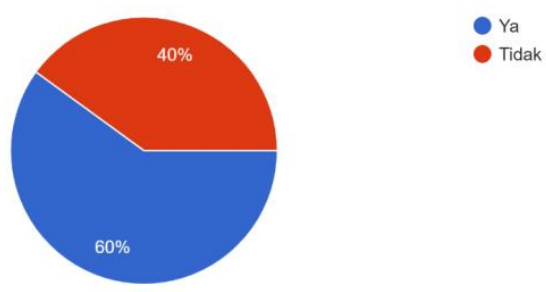

Gambar 2. Indikator Kualitas Konten

Pada proses pembuatan konten pembelajaran terlihat bahwa sebanyak $60 \%$ guru matematika melibatkan teman sejawat untuk proses validasi isi konten dan $40 \%$ guru matematika tidak menggunakan teman sejawat pada proses validasi isi konten.

Melibatkan pakar atau ahli di dalam pembuatan media pembelajaran berbasis online

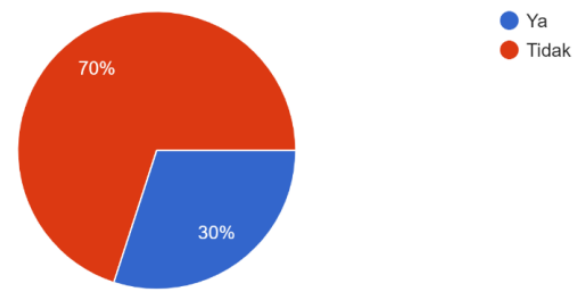

Gambar 3. Indikator Kualitas Konten

Proses pembuatan media pembelajaran online yang digunakan oleh guru-guru matematika terlihat tidak melibatkan pakar atau ahli, hanya sebanyak 30\% yang melibatkan pakar dan ahli pada proses pembuatannya.

2. Indikator keselarasan dengan tujuan pembelajaran.

Melakukan survei terhadap kondisi dan lingkungan belajar siswa
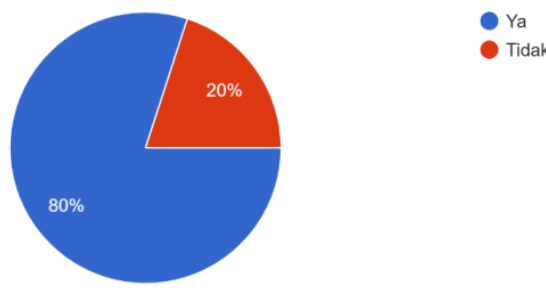

Gambar 4. Indikator keselarasan dengan tujuan pembelajaran 
Pada proses awal memulai pembelajaran online, sebanyak $80 \%$ guru matematika melakukan proses pengecekan atau survei awal terhadap kondisi lingkungan belajar siswa. Pengecekan ini dimulai dengan melihat kesiapan alat, media, dan kualitas jaringan yang digunakan oleh guru dan siswa.

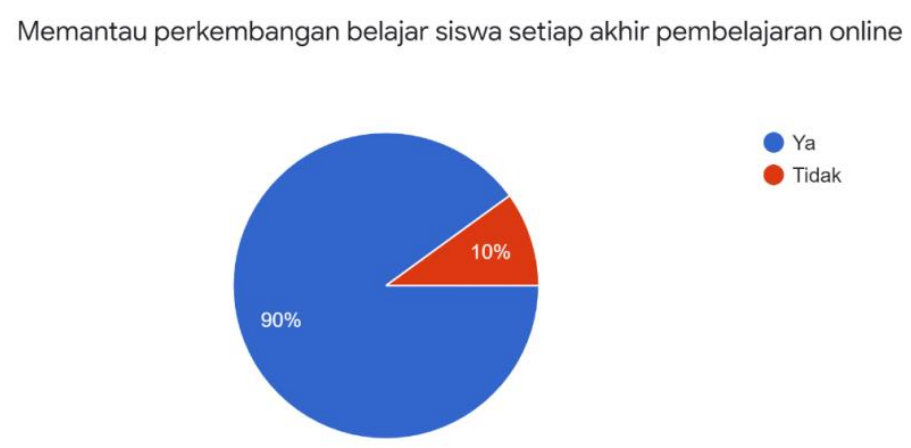

Gambar 5. Indikator keselarasan dengan tujuan pembelajaran

Hampir seluruh guru matematika yang melaksanakan proses pemantauan perkembangan belajar siswa pada setiap akhir pembelajaran online, hal ini terlihat pada gambar di atas dengan nilai sebanyak $90 \%$ dan sebanyak $10 \%$ guru tidak melaksanakan hal tersebut.

3. Indikator umpan balik

Siswa dimintai pendapat tentang materi yang telah disampaikan melalui proses online

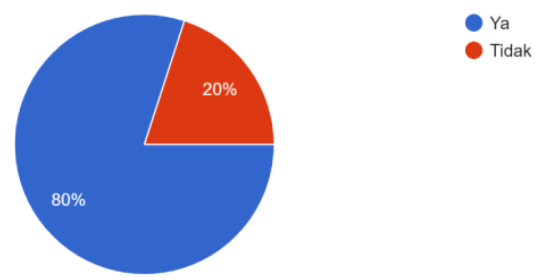

Gambar 6. Indikator umpan balik

Sebanyak $80 \%$ orang guru matematika melakukan proses mereview kembali materi yang disampaikan kepada siswa dengan melaksanakan proses tes dan $20 \%$ siswa tidak melakukan hal tersebut.

Berapa kali siswa dimintai pendapat dalam satu minggu

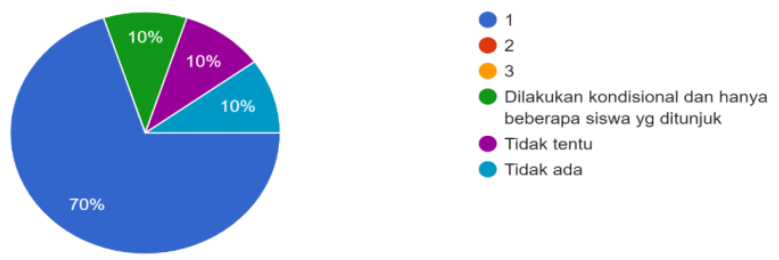

Gambar 7. Indikator umpan balik 
Kemampuan Guru Matematika Mempertahankan Substansi Materi Melalui Proses Pembelajaran Online, Febri Giantara, Astuti

Pada proses umpan balik yaitu untuk melihat sejauh mana materi yang disampaikan oleh guru matematika tersampaikan kepada siswa melalui proses bertanya langsung kepada siswa. Sebanyak 70\% orang guru matematika melaksanakan sebanyak 1 kali, 20\% dilakukan kondisional, dan $10 \%$ tidak ada.

Siswa diminta mereview atau merangkum kembali materi diakhir pertemuan
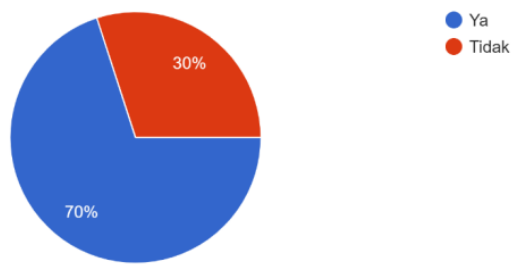

Gambar 8. Indikator umpan balik

Siswa diminta untuk mereview atau merangkum kembali materi yang telah disampaikan oleh guru pada akhir pertemuan online adalah sebanyak $70 \%$ orang guru matematika dan $30 \%$ tidak melakukannya.

4. Indikator motivasi

Memberikan penghargaan kepada siswa setiap pertemuan

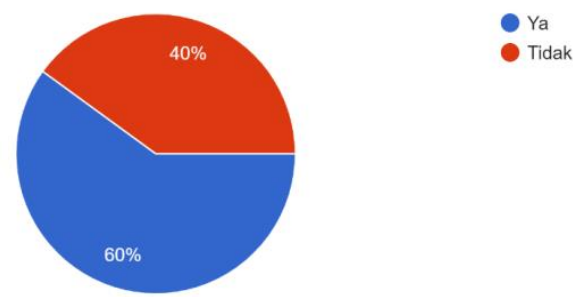

Gambar 9. Indikator motivasi

Pada indikator motivasi, guru matematika memberikan motivasi sebanyak $60 \%$ dan $40 \%$ tidak memberikan motivasi. Pemberian motivasi ini sangat penting pada proses pembelajaran online agar siswa memiliki motivasi yang sama tingginya dengan proses pembelajaran ketika mereka melaksanakan pada proses tatap muka.

Menilai dan mengembalikan tugas siswa
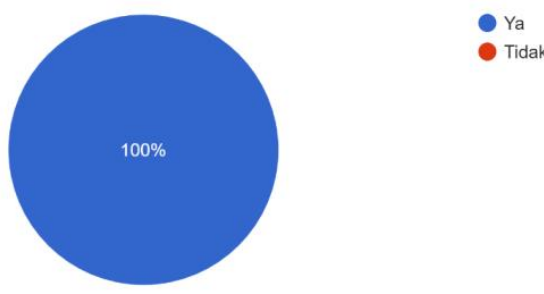

Gambar 10. Indikator motivasi 
Semua guru matematika melaksanakan proses pengembalian kembali tugas-tugas yang dikerjakan oleh siswa setelah melakukan proses penilaian. Hal ini penting untuk mengukur sejauh mana kemampuan siswa menyerap materi yang disampaikan dan dapat juga memotivasi siswa secara tidak langsung.

Membantu siswa yang kesulitan pada proses pembelajaran online

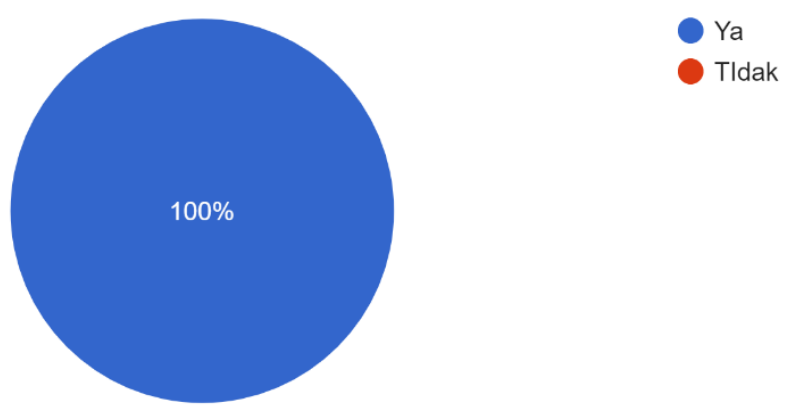

Gambar 11. Indikator motivasi

Semua guru matematika menunjukkan jati dirinya sebagai seorang guru, dengan cara membantu siswa yang kesulitan pada proses pembelajaran online. Kesulitan bisa berupa tidak pahamnya siswa dengan materi yang disampaikan.

5. Indikator hak cipta

Konten yang disajikan bukan merupakan hasil plagiasi

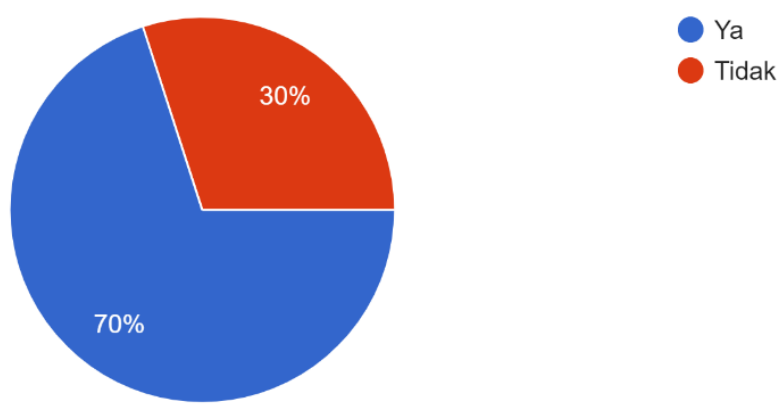

Gambar 12. Indikator hak cipta

Unsur hak cipta pada sebuah konten yang disajikan merupakan sesuatu hal yang mutlak harus dimiliki oleh seorang guru yang merupakan orang dengan intelektual yang tinggi. Sebanyak $60 \%$ orang guru matematika menyajikan konten yang merupakan bukan hasil plagiasi dan $40 \%$ merupakan hasil plagiasi. 
Kemampuan Guru Matematika Mempertahankan Substansi Materi Melalui Proses Pembelajaran Online, Febri Giantara, Astuti

Konten yang dibuat memenuhi kriteria Hak Kekayan Intelektual (HKI)

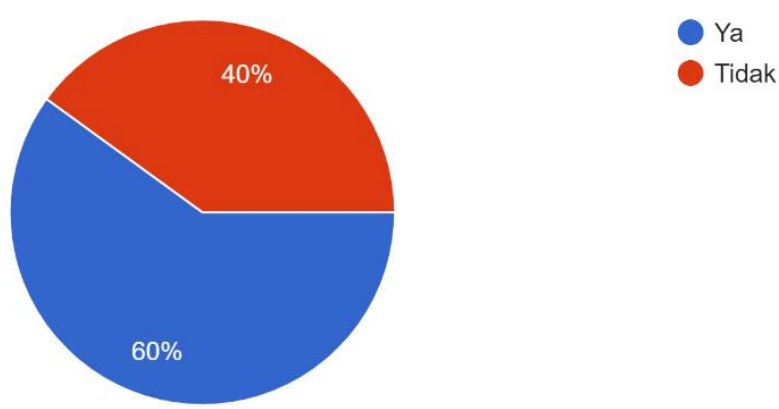

Gambar 13. Indikator hak cipta

Konten yang disajikan oleh guru matematika hanya 60\% yang memenuhi kirteria Hak Kekayaan Intelektual (HKI) dan 40\% lagi tidak memenuhi unsur tersebut. Sedikitnya guru matematika yang mematuhi kriteria hak cipta menunjukkan ketidakpahaman guru matematika betapa pentingnya hal ini dilaksanakan.

\section{KESIMPULAN}

Kesimpulan pada penelitian kemampuan guru matematika memperatahankan substansi materi melalui proses pembelajaran online adalah 1) Guru matematika belum sepenuhnya memperhatikan kualitas konten materi yang disampaikan pada proses pembelajaran online. 2) Guru matematika memperhatikan tercapainya tujuan pembelajaran melalui proses pembelajaran online. 3) Guru matematika memberikan umpan balik dan motivasi kepada siswa melalui proses pembelajaran online.

4) Guru matematika kurang memperhatikan Hak Kekayaan Intelektual pada proses pembelajaran online. 5) Saran untuk penelitian berikutnya agar peneliti menggunakan seluruh indikator dan menganalisis kendala yang terjadi ketika proses pembelajaran online berlangsung.

\section{DAFTAR PUSTAKA}

Daud, A. (2020). Strategi Guru Mengajar Di Era Milenial. Al-Mutharahah: Jurnal Penelitian Dan Kajian Sosial Keagamaan, 17(1), 29-42. https://doi.org/10.46781/al-mutharahah.v17i1.72

Giantara, F. (2019). Model Pengembangan Kompetensi Guru Abad 21. Al-Mutharahah: Jurnal Penelitian Dan Kajian Sosial Keagamaan, 16(1), 59-83.

Giantara, F. (2020). Analisis Data (Kualitatif, Kuantitatif, Metode Campuran, dan Penelitian Tindakan). (N. Yanti, Ed.). Pekanbaru: LPPM STAI Diniyah Pekanbaru.

Handayani, L. (2020). Keuntungan, Kendala dan Solusi Pembelajaran Online Selama Pandemi Covid- 
19: Studi Ekploratif di SMPN 3 Bae Kudus. JOURNAL INDUSTRIAL ENGINEERING \& MANAGEMENT RESEARCH ( JIEMAR), 1(2), 2722-8878. https://doi.org/10.7777/jiemar.v1i2

Ihsanuddin. (2020). Fakta Lengkap Kasus Pertama Virus Corona di Indonesia. Retrieved June 5, 2020, from https://nasional.kompas.com/read/2020/03/03/06314981/fakta-lengkap-kasuspertama-virus-corona-di-indonesia

Leavy, P. (2017). Research Design. New York: The Guilford Press.

Ruziana, D., \& Prihatnani, E. (2019). Kreativitas Siswa Produk Kurikulum 2013. Jurnal Cendekia: Jurnal Pendidikan Matematika, 3(1), 73-81. https://doi.org/10.31004/cendekia.v3i1.88

Sukmadinata, N. S. (2010). Metode Penelitian Pendidikan. Bandung: Remaja Rosda Karya.

Wibawanto, H. (2017). Instrumen Evaluasi Kualitas Pembelajaran Daring dalam SPADA Indonesia. Semiloka Pembelajaran Daring di Perguruan Tinggi. Surabaya. Retrieved from http://www.merlot.org

Wirawan. (2012). Evaluasi Teori, Model, Standar, Aplikasi, dan Profesi. Jakarta: Rajawali Pers. 